\title{
PUNS IN ALICE IN WONDERLAND AND THEIR EQUIVALENTS IN MACEDONIAN
}

\author{
Sandra Ivanovska
}

Ss. Cyril and Methodius University, Skopje

sandra_ivanovska.96@live.com

This paper explores the puns in Lewis Carroll's Alice in Wonderland, with a special focus on their types, as well as their Macedonian equivalents. Its aim is to discover on which linguistic techniques the puns are based on, and to present the varieties of their Macedonian translations - where they differ, where they are similar, which techniques are used by the translators, and whether the translations are 'successful'. This is achieved through a comparative analysis of the original puns and their six translation varieties in Macedonian. Besides comparing the original with its translation varieties, the author provides a comparison between the translation varieties as well, highlighting the strategies used by the translators and comparing the variations based on their preferred translation strategy. The findings reveal that the focus of the majority of the translators is mainly on the recreation of the puns by using creative linguistic solutions. Otherwise, the result is an incoherent piece of text, which neither the readers nor the translators themselves can comprehend.

Keywords: puns, wordplay, translation, Alice in Wonderland, humour 


\section{ИГРАТА НА ЗБОРОВИ \\ ВО АЛИСА ВО ЗЕМЈАТА НА ЧУДАТА И НИВНИТЕ ЕКВИВАЛЕНТИ ВО МАКЕДОНСКИОТ ЈАЗИК}

Сандра Ивановска

Универзитет „Св. Кирил и Методиј“, Скопје

sandra_ivanovska.96@live.com

Целта на ова истражување е да ја претстави и да ја анализира играта на

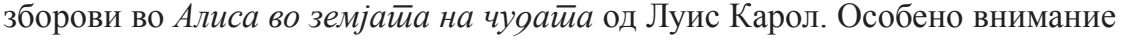
е посветено на различните видови игра на зборови, како и нивните македонски преводи. Целта на трудот е да се види на кои лингвистички техники е базирана играта на зборови и да ги претстави различните варијанти на нејзините македонски еквиваленти - каде се слични, а каде различни, кои техники се употребени од страна на преведувачите, како и дали е нивниот превод успешен. Избраната техника за оваа анализа е да се направи компаративна анализа меѓу оригиналот и преводите, како и меѓу шесте превода меѓусебно. Авторката заклучува дека најголем дел од преведувачите се стремат да го пренесат значењето на играта на зборови од оригиналот на македонски јазик - некои обиди се успешни, некои се доволно добри, но некои се и разочарувачки.

Клучни зборови: игра на зборови, јазични досетки, превод, Алиса во земја-

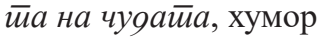




\section{Introduction}

Alice's Adventures in Wonderland (aka, Alice in Wonderland) is the first of two well-loved children's books about the extraordinary adventures of young Alice in a fairytale-like world, the product of the imagination of Charles Lutwidge Dodgson, better known as Lewis Carroll. Though seemingly timid and introspective, Carroll's vivid imagination and originality created a whole new world filled with unique and eccentric inhabitants. After its publication in 1865, the book became an instant bestseller, skyrocketing Carroll to fame, and prompting the publication of its sequel, Through the Looking-Glass, and What Alice Found There, six years later.

Despite the captivating world and story Carroll created, it is his writing style - witty and unconventional, full of clever references, satire, parody, and fascinating language games and wordplay, which made the story so popular and relevant. Wordplay, puns specifically, are the object of interest in this paper - their type, meaning, and their Macedonian equivalents.

\section{Overview}

"Why is a raven like a writing-desk?" is one of the most famous riddles in literature, posed to Alice by the Hatter. Its answer remained a mystery for 31 years, during which time it grabbed the attention of many who attempted to figure it out. Ultimately, none were successful until Carroll himself provided the answer in the preface of the book's 1896 revision - "Because it can produce few notes, tho [sic] they are very flat; and it is nevar put with the wrong end in front!" Note that the misspelling of 'never' is intentional, as it is actually the word 'raven' with the wrong end in front. Despite Carroll having provided the long-awaited answer, people continued to propose their own answers to the riddle, some even entering competitions held for that purpose. This is a testament to the tremendous influence of Carroll's language, which has prompted the writing of numerous books, dissertations, and papers - it has been analysed and researched in various contexts throughout the last millennium. Therefore, aiming to contribute to the corpus of research on Carroll's language, the purpose of this paper is to provide an overview and commentary on the puns found in one of the most critically-acclaimed children's classics of our time - Alice in Wonderland. Although only a seemingly small piece of the pie that is Carroll's arsenal of wordplay, word-games, and riddles, the simultaneous complexity and simplicity of his puns make them one of the most memorable and quotable parts of the book.

The aim of this analysis is to see how the Macedonian translators dealt with the challenge of translating puns - which techniques they used, or did not use, whether their puns mirror the original, were replaced with new ones, or were simply lost in translation. This will be a mixed study combining both a qualitative overview of the puns and their translations, as well as a quantitative approach to measuring the results of the analysis of the strategies used for translating. The author believes that 
this study will provide a more in-depth review of Macedonian translations of puns, which is a topic that has not attracted much attention in the past, thus providing a "starting position" for other similar research to follow.

\subsection{Literature review}

Before delving into the analysis of this paper, it is of great importance to mention some previous studies done on the topic. Hence, the purpose of this section is to provide a short overview of three studies focusing on the translation of Alice in Wonderland into three languages: Albanian, Russian, and Italian. The focus of the first two is specifically on the translations of the puns in Alice in Wonderland, while the study of the Italian translations focuses on various aspects of the book, thus providing a more general analysis.

\subsubsection{Translating Alice in Wonderland - examples from past studies}

In a study of the Albanian translations: " $(\mathrm{Re})$ Creating the Power of Language: A Comparative Analysis on Pun Translation in 'Alice's Adventures in Wonderland' and Its Variants in Albanian" published in 2013, Eriola Qafzezi took on the task of analysing the Albanian translation of puns in Alice in Wonderland. Qafzezi (2013: 212-224) analysed five variants of Albanian translations of 29 puns "which include several types and subtypes of puns such as malapropisms, paronymous words, homonyms, polysemantic words, homophones, homographs, idioms, etc." Four strategies were identified to have been used by the translators, each strategy being backed up with examples from the book:

Strategy \# 1 - Reproducing ST (source text) puns in the TT (target text)

Strategy \# 2 - Translating the ST pun components without reproducing a pun in TT

Strategy \# 3 - Omission of the ST pun in the TT

Strategy \# 4 - Transferring the ST pun in the TT (Qafzezi 2013).

Following the completion of the analysis, the results were presented in the form of a graph and pie charts, with the results having been converted into percentages to determine the frequency of usage of each strategy by each translator. Upon finishing the analysis of the translation variants, the author of the paper decided to add one more final strategy: "Compensating for loss of ST puns by introducing new puns in the ST" (Qafzezi 2013: 219). Finally, Qafzezi (2013: 220) concluded that the most frequently-used strategy is the second one - "Translating the ST pun components without reproducing a pun in TT," and added that "the percentage of this strategy has been rising from the first variant (42\%) up to the last $(63 \%)$, whereas the percentage of the strategy of reproducing ST pun in the TT has been declining through the years." However, it was noted that more than one third of the corpus was composed by reproducing ST puns in the TT - a fact that the author of the paper considered positive. Lastly, only $2 \%$ of the puns had been omitted, while $12 \%$ had been further explained in footnotes or brackets. Similarly, the second study also analysed the translations in regards to the translation strategies used by the translators. Conducted by Per Ambrosiani in 2010, it holds the title: "A Russian Tail? On 
the Translation of Puns in Lewis Carroll's Alice's Adventures in Wonderland." In the introduction, Ambrosiani stated the following: "The discussion of the present investigation will focus on horisontal word-play and its translation into Russian. The source text (ST) material includes three puns in the text of Alice's Adventures in Wonderland" (2010: 32). The analysis included 12 translations ranging from the years 1908 to 2006 - almost a century. The three translation strategies used are based on Delabastita's (1993: 202-210) model:

1. PUN $>$ ZERO. The source text (ST) that contains the pun is not translated, and the corresponding target text (TT) is omitted.

2. PUN $>$ NO PUN. The meanings of the ST expressions P 1 and P 2 are both present in the TT, but the wordplay meaning (F) is lost in the translation.

3. PUN $>$ PUN. The focus in this type of translation is on the wordplay meaning that is present in the ST. In addition to the wordplay meaning (F), which is more or less similar to the ST F, the TT can focus on the following meanings in the ST: a) the meanings of both $\mathrm{P} 1$ and $\mathrm{P} 2$; b) the meaning only of P 1 ; c) the meaning only of P 2; d) the meanings of neither P 1 nor P 2. (Ambrosiani 2010: 33)

In the conclusion of this study, it was stated that three translators used source-oriented strategies, two preferred target-oriented strategies, one combined different strategies, taking "an in-between position in the choice between source- and target-oriented strategies" (Ambrosiani 2010: 56). Finally, the author noted that the remaining translations were not easy to classify because they combined both characteristics.

The third and final study, "Alice's Adventures in the Italian Land: Translating Children's Literature in Italy across a Century (1872-1988)" took a more philosophical rather than a linguistic approach. It was not focused solely on puns, but on the translation of various aspects of the book - nursery rhymes and intertextual references, wordplay, proper names, historical figures and cultural references, Alice's identity, and omissions, changes and other textual alterations. The aim of the study was to see the manner in which the historical and social changes in Italy had influenced the translation of Alice in Wonderland throughout the years. According to Berrani (2017: 108-205), the study contained two types of investigation - synchronic, examining the "relationships between text, translator and historical setting" and diachronic, examining the evolution of relationship between the novel, the Italian translators and Italian setting. The conclusion of the synchronic study was that "all the translation of Alice in the corpus displayed an inconsistent application of the translation strategy, due to the translators' necessity to adjust to different parts of the text", while the diachronic study led the author to the conclusion that "the orientation of the translations of Alice in the corpus changed in time from child- oriented towards adult-oriented" (Berrani 2017: 244).

\subsection{Macedonian translations}

At this time there are six published Macedonian translations of Alice in Wonderland. The first translation of the book, in 1957, was by Slavcho Temkov, which was followed by Bogomil Gjuzel's translation in 1978. After a long break came Silvana Acevska's translation, in 2009, followed by Negica Glasnovikj's transla- 
tion in 2013, and then five years later, in 2018, the translation by Marija Petrovikj. The last, and most-recently published translation is by Rumena Buzharovska, in 2019. Something that should be noted is the similarity of Petrovikj's translation to Acevska's and Gjuzel's translation. In her paper "Translating Lewis Carrol's Alice in Wonderland Poems Into Macedonian" Buzharovska states that "... - it would be hard to call this a translation, even, as the poems are clearly plagiarized, mostly from Acevska's work, with two poems having been stolen from Gjuzel's translation" (2020: 250). As the author of this paper, I feel it is my responsibility to point out this accusation so that the reader takes it into account. No claims will be made regarding the authenticity of the translations of the puns; that matter will be left up to the readers to decide on their own.

\section{Wordplay vs. pun}

In order to fully comprehend the definition of a pun, we first need to make the distinction between the terms wordplay and pun, which are often used interchangeably though they refer to different things.

Wordplay is a compound composed of word + play, and its meaning can be deduced from its elements: a play with words. Beneath its deceptively simple name lies a concept which is hard to define, with many scholars still struggling to settle on a unified definition. The 6th edition of the Oxford Advanced Learner's Dictionary defines wordplay as "making jokes by using words in a clever or amusing way, especially by using a word that has two meanings, or different words that sound the same" (2000: 1375). This is a simplified explanation of the concept, which in reality is a very broad term that encompasses many aspects of language. Dirk Delabastita (1996), a prominent researcher in the field of wordplay, understands wordplay as a more general term which encompasses the exploitation of different textual phenomena, resulting in a two or more linguistic structures with similar forms and different meanings. Additionally, Thaler's (2016) classification of wordplay according to the linguistic techniques used illustrates the full scope of the 'textual phenomena' which constitute it; the techniques are classified into four groups: phonetic, lexical, morphological, and orthographic and graphic.

The phonetic techniques include plays on: homophony, similarity of pronunciation, permutation of sounds (spoonerisms), rhythm and rhyme, and alliteration and assonance.

The lexical techniques include plays on: homonymy, paronymy, polysemy, phraseological elements (idioms or sayings), and lexical sets.

The morphological techniques are: ludic alternation of morphemes (play on morphemes), and ludic word formation (plays on: compounding, portmanteau words, derivation, acronyms, and comparative forms).

Finally, the orthographic and graphic techniques consist of: a play on orthographic variations, shifting of word boundaries, palindromes, and a play on typographic elements.

The complexity and vastness of this classification reveals the true nature of wordplay - the creation of these seemingly simple and amusing language games involves numerous linguistic techniques. Thus, it may be concluded that wordplay is 
a general term for a wide spectrum of various techniques which can be used individually or combined in order to achieve a play on words. Emphasis should be placed on the word 'general,' because it is the key element that differentiates wordplay from puns; the former encompasses all variations of language techniques involved in using language creatively, while the latter are only one branch of the wordplay tree. While wordplay is the general term used for all language games, puns are a subtype of wordplay. However, due to the popularity of puns among all language users, they have become the most famous out of all the other subtypes of wordplay. This has contributed to them being regarded as the only aspect of wordplay at times, resulting in the two terms being used interchangeably and synonymously. In his Language Play, Crystal (1998: 1-2) notes the connection between the standard responses regarding the aim of language, which are usually "communication" or "transmission of knowledge," as well as how 'ludic,' or 'playful' language fits into that definition. After providing an example of ping-pong punning, which Crystal describes as an act when the humour bounces back and forth between the speakers, he comments on the position of ludic language as compared to "regular" language:

It is difficult to see how ping-pong punning can possibly fit in with the view that the purpose of language is to communicate ideas. For what new knowledge is being transmitted between the participants, as they bounce jokes off each other? None. What have they learned, at the end of the sequence, that they did not know before? Nothing. There seems to be a tacit agreement that none of their language is to be taken at its face value, while the exchange is in progress - that no sentence is to be interpreted as containing any real information (Crystal 1998: 4)

Crystal's interpretation of why language play is sometimes considered to be a lower form of language correlates to the reason for the low reputation of the humble pun. The reception of the pun is divisive - people either love it or hate it. The former hail the pun as witty and clever, and appreciate the unconventional and creative usage of language; the latter consider it a cheap and cheesy form of humour, and see puns as a second-class form of language. However, as Crystal states previously, the function of the pun is not to exchange information, nor to communicate - its function is to amuse and entertain, which is why it should not be taken too seriously.

The 6th edition of the Oxford Advanced Learner's Dictionary defines pun as "the clever or humorous use of a word that has more than one meaning, or of words that have different meanings but sound the same" (2000: 945). As with wordplay, there is no one agreed upon definition of a pun. The lines are blurred on what constitutes a pun, and what is considered wordplay. However, for the purpose of this paper, and so as to avoid further confusion, the Oxford definition will be accepted as one that encompasses the essence of what a pun is. Even after having defined puns, classifying them is a challenging task. Pollack (2012: 9-27) presents a number of pun categories in his The Pun Also Rises. He acknowledges the overwhelming differences in schools of thought on which words classify as puns, and presents an overview of all contenders: homophonic and homographic puns, paradigmatic and syntagmatic puns, the Spoonerism, the chiasmus, Wellerisms, Tom Swifties, "shaggy dog" puns, Feghoots, knock-knock jokes, and daffynitions. 
Delabastita differentiates between vertical puns, the components of which are "represented simultaneously within one and the same portion of text, i.e. in a paradigmatic matter," and horizontal puns, whose "confrontation is realized through a syntagmatic relationship, the two components occurring one after another in the linear series of the syntagm in which the pun is embedded" (Delabastita 1993: 79). Delabastita (1993: 80-81) offers another classification of puns: homonymic, homophonic, homographic, and paronymic. This is the classification that will be implemented in the analysis segment of this paper. A short definition for each class is provided in section 5 below.

Due to the fluid nature of language and wordplay there seems to be no consensus on only one universal definition and classification of puns. This paper presents its author's subjective perception of the topic at hand, and acknowledges the existence of other, differing viewpoints on the topic.

\subsection{The language of Lewis Carroll}

In his book Language and Lewis Carroll, Sutherland provides a compelling description of Carroll's approach to language:

Without greatly concerning himself about underlying theoretical principles, Carroll simply capitalized upon the functional characteristics of language which, as revealed in general usage, offered inherent possibilities for absurdity. He saw that, at least part of the time, most people are careless in their use of language, that they often confuse the symbols with the things symbolized, invest words with a 'magical' autonomy, and fall prey, through their carelessness, to lexical and structural ambiguity. He saw that much in conventional usage is quite illogical when viewed from a vantage point outside the conventions, and realized that humor could be derived from treating these usages in a strictly logical and non-conventional manner (1970: 28).

In the same chapter, Sutherland also gives a brief mention of Carroll's fascination with the alphabet. Namely, during his lifetime, Carroll published three wordgames: Doublets (1879), Mischmasch (1882), and Syzygies (1891); he was also great at inventing anagrams, some examples of them being: "Edward Vaughan Kenealy' becomes 'Ah We dread an ugly knave', and 'Florence Nightingale', 'Flit on, cheering angel"' (Sutherland 1970: 23). Also mentioned is Carroll's habit of "writing cryptograms to his child-friends" (Sutherland 1970: 23) after inventing "The Alphabet Cipher" and "The Telegraph Cipher" - he wrote four ciphers in total. Carroll also wrote acrostics, and had some attempts at symbolic manipulation. Additionally, Sutherland notes that "play with words as whole units finds its most characteristic expression in Carroll's neologisms and puns" (1970: 24). Some of Carroll's most well-known coined words include: snark, mimsy, and chortle, among others.

Someone so involved in exploring language would be assumed to have a linguistic background; yet Carroll was no linguist - he was only a man fascinated by language. Alice in Wonderland is a statement of his genius and unique way to play 
with language - it is riddled with language play: numerous nonsense words and neologisms, riddles, jokes, and wordplay based on various aspects of language. Out of the various forms of wordplay he used, what stands out the most are puns, most of which are based on phonology, lexicology, and semantics - the gist of the pun usually relies on the words' pronunciation, their form and role in the sentence, and their meaning. In regards to Carroll's stance on meaning, Háhn (2010) provides an interesting observation:

...he questioned the relevance of the definite relationship between the signifier and the signified and provided an interesting definition of meaning. In AAW [Alice's Adventures in Wonderland] and in TLG [Through the Looking Glass], the theory of meaning is the following: the meaning of an expression is determined by the intention that the speaker wishes to express with it (2010: 91).

Háhn (2010) also notes that for successful communication to occur, the intention of the speaker must be perceived by the listener - there must be a "mutual understanding." Puns are so popular because they are entertaining, yet if the gist of the pun is not understood by its audience, then a breakdown in communication occurs. The simplicity of Carroll's puns makes them easy to understand, establishing a connection between the characters and the reader; this connection has kept Alice in Wonderland relevant and popular among audiences of all ages.

\section{Methodology}

The comparative analysis method has been selected as the most suitable for the purpose of conducting this analysis of puns in Alice in Wonderland, and their Macedonian equivalents. For this analysis, the author does not follow any established comparative analysis method, but has developed a customized method they feel suits this subject in particular. A brief clarification of what this method of choice entails is explained in the next paragraph.

Using Delabastita's previously-mentioned classification model, a selection of puns are first classified into three groups based on their type: homographic, homonymic, and paronymic. Each pun is then analysed and compared with a selection of its Macedonian equivalents. Additionally, the translations themselves are compared as well, with a focus on the types of strategies used in the translation process.

\subsection{The puns}

For the purpose of the research, nine puns from the ST (source text) have been selected, with examples from each class. Due to the nature of the book, every re-reading of it may result in new discoveries of nuances regarding its language, as well as hidden meanings and wordplay, which may previously have gone unnoticed. Also, since there is no clear-cut line between puns and wordplay, some instances may fall in a "grey area" between the two. In order to avoid confusion, all examples here are clear-cut instances of puns. The exact number of puns in the ST is not stated here, the focus being on a group of well-known and obvious puns. 


\subsection{The translations}

All six Macedonian translations of Alice in Wonderland are analysed, with two types of comparisons: between the ST and the TT, as well as among the TTs. Not all translation varieties are mentioned for every pun - the ones included are selected according to the author's personal judgement so as: 1. to avoid repetition of similar translations, and 2. to avoid overwhelming the reader with too much information.

\section{Alice in Punderland - an analysis of puns and their Macedonian equivalents}

Following Delabastita's (1993: 80-81) model, the selected puns from Alice in Wonderland are classified into three groups: homophonic, homonymic, and paronymic. Though Delabastita's classification includes an additional group - homographic puns, no instances of this group have been identified in the book.

\subsection{Homophonic puns}

Homophonic puns are puns based on the sameness of the pronunciation of a word or word group. Although their pronunciation is the same, their spellings and meanings differ.

"Mine is a long and a sad tale!" said the Mouse, turning to Alice, and sighing.

"It is a long tail, certainly," said Alice, looking down with wonder at the Mouse's tail; "but why do you call it sad?"

As seen from the first example, the pun is based on a play on the identical pronunciation of tale and tail -/terl/. This homophony causes a misunderstanding between the Mouse and Alice. None of the Macedonian translations have translated this excerpt with a pun; most of them have omitted the wordplay aspect of the exchange and have opted for finding a way to include the Mouse's tail into the conversation, usually with Alice pointing out its length and comparing it to the length of the Mouse's story. However, this has resulted in an omission of the misunderstanding which occurs in the original. In Petrovikj's translation, "why do you call it sad?" refers to the story, not the Mouse's tail.

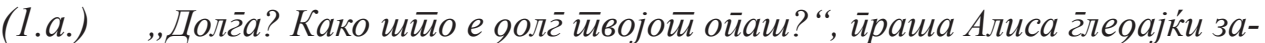

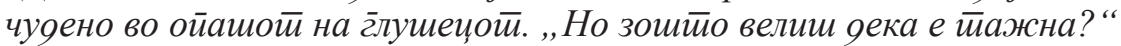
(Петровиќ 2018: 24)

Back translation:

"Long? Like your tail?" Alice asked, looking down with wonder at the Mouse's tail; "but why do you call it sad?"

On the other hand, Gjuzel manages to transfer the misunderstanding into his translation, though stripped of puns and wordplay: 


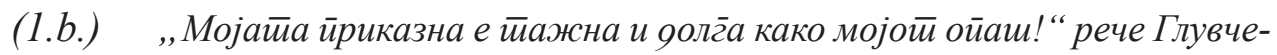
ӣо сврӣувајќи се кон Алиса и возоивнувајќи.

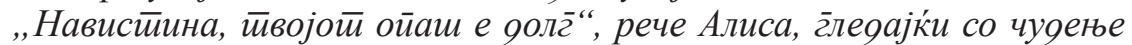
во ойашой на Глувчетио; ,но не разбирам зошито рече яека е йажен? “(Ѓузел 1978: 21)

In this version, the Mouse says that its story is sad and long, like its tail. However, these are two separate statements: 1. Its story is sad; 2 . Its story is long like its tail. The source of the misunderstanding is that Alice thinks both adjectives refer to the tail.

Another interesting take is Buzharovska's, where Alice herself makes the connection between the Mouse's tale and tail - the Mouse's tale is long and sad, so if the Mouse's tail is long (which it is), does that imply that it is also sad?

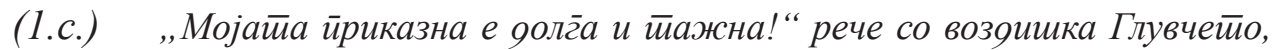
врйејќи се кон Алиса.

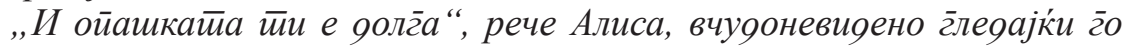

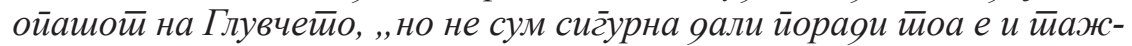
на? “ (Бужаровска 2019: 32)

(2) "I beg your pardon," said Alice very humbly: "you had got to the fifth bend, I think?"

"I had not!" cried the Mouse, sharply and very angrily.

"A knot!" said Alice, always ready to make herself useful, and looking anxiously about her. "Oh, do let me help to undo it!"

This is another example of a pun based on homophony. Both not and knot are pronounced as $/ \mathrm{ntt} /$. Similar to the previous example, the homophony results in a misunderstanding between Alice and the Mouse.

Two translations have managed to successfully adapt the pun into Macedonian by using minimal pairs rather than homophones, like in the original. Gjuzel - with the help of the words јазол (knot), and јазел (crept), Buzharovska - using a more informal synonym for јазол-чвор and pairing it with збор (word).

(2.а.) „Не сум внимавал на нишӣо и на нишӣо не сум се јазел!“” иे викна Глувчейо луйо.

„А-а, јазол!“” рече Алиса, секогаши горйова яа каже нешимо корисно и гллеgајќи загррижено околу себе. „Ах, ие молам, йомог̄ни ми яа г̃о оомрсам! “ (Гуузел 1978: 22)

(2.b.) „За тиоа не йаяна ни збор!'“ остиро и луйо извика Глувчейо.

„Чвор?" рече Алиса, која вознемирено се обsрна наоколу, ойи секо-

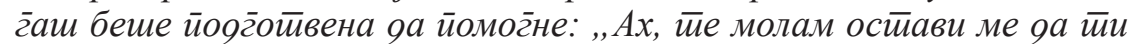
йомог̄нам яа г̃о ояврзеш! “ (Бужаровска 2019: 33) 
On the other hand, Glasnovikj's translation confuses the reader because Alice's exclamation about the knot makes no sense in the context of the exchange. The Mouse exclaims "NO!" and then Alice mentions the knot seemingly with no reason.

(2.c.) „НЕ!“ извика Глушещот̄ остиро и налуиено. „Јазол!“ рече Алиса. (Гласновиќ 2013: 25)

You see the earth takes twenty-four hours to turn round on its axis - " "Talking of axes," said the Duchess, "chop off her head!"

The homonymy of axis and axes in this excerpt does not cause a misunderstanding, but rather it prompts the Duchess to order a beheading.

The majority of the translators successfully transfer the pun into Macedonian by using the Macedonian homonym секира, whose meanings are:

M1: an axe

M2: to worry

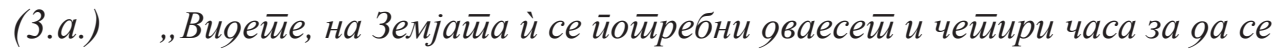

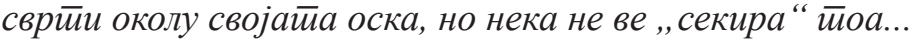

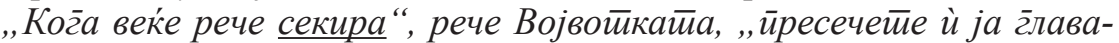
$\bar{u} a !$ " (Ацевска 2009: 44)

Temkov takes a different approach - he focuses on a different part of the ex-

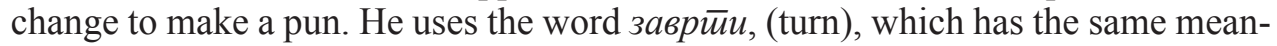
ing in both of the places it is used, however, the context differs. The first time it refers to the turning of the Earth, and the second time it is used in the expression 'to turn someone's neck', which in Macedonian means 'to kill someone.'

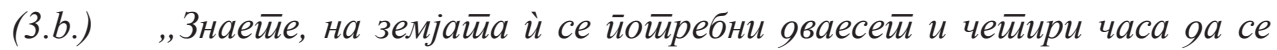
завриии околу својайа оска..."

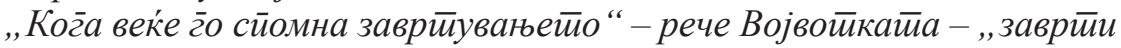

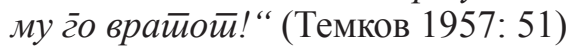

The only translation in which the pun is ignored is Glasnovikj's. It seems like the translator does not get the gist of the pun, because she translates both axis and axes the same - оска, meaning axis, and changes nothing in the rest of the exchange. The result is a very confusing sentence:

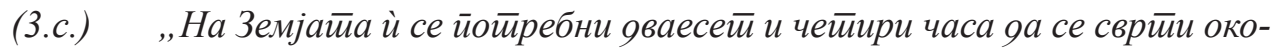
лу својашиа оска... “

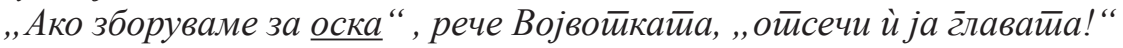
(Гласновиќ 2013: 48) 


\subsection{Homonymic puns}

The homonymic puns in Alice in Wonderland are based on homonymy, i.e. the identical spelling and pronunciation of words that have different meanings.

"Are you all ready? This is the driest thing I know. Silence all round, if you please! 'William the Conqueror, whose cause was favored by the pope, was soon submitted to by the English..."

To put the pun in context, the Mouse is offering to tell this story to dry those that got wet from Alice's tears. Since this is a homonymic pun, dry has two meanings: M1: not wet, damp or sticky; without water or moisture; M2: not interesting

Temkov, Acevska, and Buzharovska successfully adapt the pun by using the word сувойарно, which means boring; dull. Сувойарно, unlike dry, does not have two meanings, but its root is суво (dry), implying a second meaning to the word. Moving from left to right, the translators use three degrees of the adjective: positive (сувопарно), comparative (посувопарно), and superlative (најсувопарната).
(4.а.) „Ḱе ви ооржам еяно сувойарно ирреяавање.” (Темков 1957: 24) „Посувойарно оя ова не знам яа раскажам." (Бужаровска 2019: 28) ", ... најсувойарнайа рабойа шито ја знам." (Ацевска 2009: 19)

The other translations lack the double meaning of $d r y$ and convey only its original meaning - without water or moisture, which makes the following lines confusing to the readers. One such example is in Gjuzel, who translates $d r y$ as cyвo, which is its correct translation, however, the reason for telling the story about William the Conqueror later on in the text is lost to the reader.

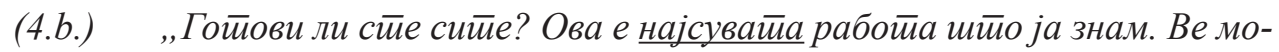

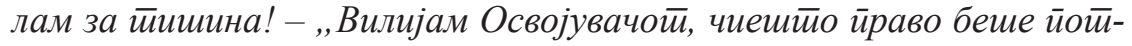

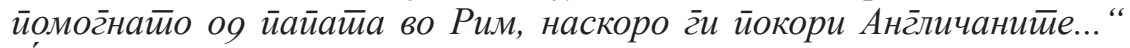
(Гуузел 1978: 18)

"... there's a large mustard-mine near here. And the moral of that is 'The more there is of mine, the less there is of yours",

The homonymic nature of this pun is achieved with the word mine. Its two meanings are: M1: a deep hole or holes under the ground where minerals such as coal, gold etc. are dug; M2: of or belonging to the person writing or speaking. The successful adaptations capture the fact that the expression "The more there is of mine, the less there is of yours" makes no sense in the context of the exchange, but is only there to make a pun with mine, so the translators heavily edit their expressions in order to capture the essence of the original pun. Gjuzel's adaptation makes a pun by substituting the moral from the original with a well-known Macedonian proverb containing the word койa so as to make a pun with искойува, which has $\kappa о \bar{u} a$ as its root. 
(5.а.) „Овяе во близинайа има еяен руяник оя кој се искойува сенф. А йо-

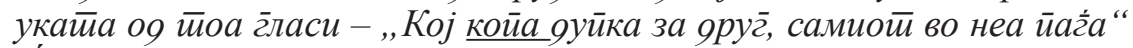
(Ѓузел 1978: 65)

(5.b.) „... йука во близина има ковачнииа за сенф. А наравоучениейо йука

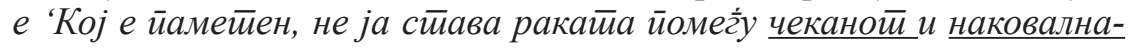
ua '“ (Бужаровска 2019: 104)

Buzharovska takes greater liberty in adapting the pun, where the mine becomes a forge (ковачница), and the moral is changed to contain the words чекан (hammer) and наковална (anvil). Other than the obvious relationship between a forge and the objects found in it, both ковачница and наковална have the same root - the verb кове.

The rest of the translations ignore the pun and resort to an almost literal translation of the exchange:

(5.c.) „Во близина има еgен голем руяник за сенф. А йоукайа е: “Колку йовеќе има за мене, йебе сѐ йомалку тии се йишува."

(Ацевска 2009: 66)

(6) "Thank you," said Alice, "it's very interesting. I never knew so much about a whiting before."

"I can tell you more than that, if you like," said the Gryphon. "Do you know why it's called a whiting?"

"I never thought about it," said Alice. "Why?"

"It does the boots and shoes," the Gryphon replied very solemnly.

Alice was thoroughly puzzled. "Does the boots and shoes!" she repeated in a wondering tone.

"Why, what are your shoes done with?" said the Gryphon. "I mean, what makes them so shiny?"

Alice looked down at them, and considered a little before she gave her answer. "They're done with blacking, I believe."

"Boots and shoes under the sea," the Gryphon went on in a deep voice, "are done with whiting. Now you know."

The word of relevance in this elaborate pun is whiting, and its two meanings are: M1: a small sea fish with white flesh that is used for food

M2: paint or turn (something) white

Temkov and Buzharovska both choose the same homonym as a solution - pибa, whose meanings are: M1: (as a noun) a fish M2: (as a verb) scrub.

(6.а.) „Благоооарам“-рече Алиса. „Многуу е иниеересно. Сега многуу йовеќе знам за рибичкииее."

„Можам яа тии раскажам и йовеке за нив ако сакаш“ - ояг̄овори

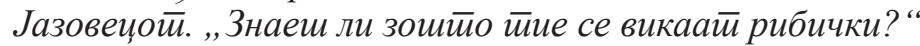

„Никог̃аш не сум размислувала за йоа“ - оэг̃овори Алиса. „Кажи зошӣ̄o? “ 
„Зайоа шимо чисииай чевли“- оэг̄овори Јазовецой мошне сериозно. Алиса беше сосема збунетиа.

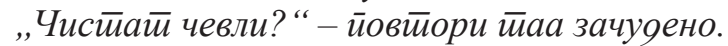

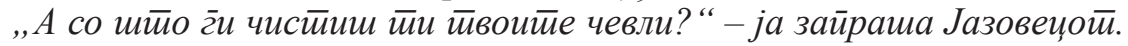

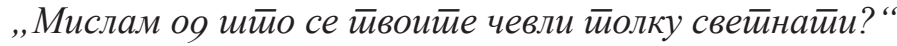

Алиса йог̆леgна во своиие чевли, малку се йоэзамисли и яури тиог̄аш оэг̄овори:

„Ги чистиам со чейка за чевли. “

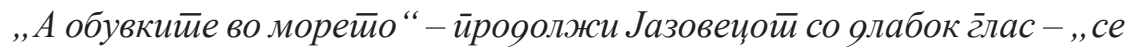
чистиай со рибање. Сег̄а сигуурно йи е јасно!" (Темков 1957: 96-97)

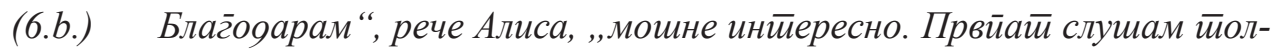
кумногу за белитер риби."

„,Можам ушие gа йи раскажам, ако сакаш“, рече Грифоноти. „Знаеш ли зошито се вика бела риба?"

„Никогаш не сум йомислила на йоа“, рече Алиса. „Зошӣо?

„Зашӣо служи за светикање чизми и чевли“, рече многуу сериозно Грифоноте.

Алиса сосема се збуни. „За чизми и чевли? “ иовйори, зачуяено.

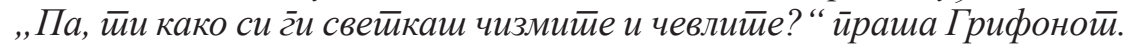

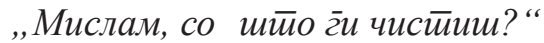

Алиса си г̄и йог̆леgна и йооразмисли йреg gа ояг̃oвори. „Со рибање? Со ирна боја?"

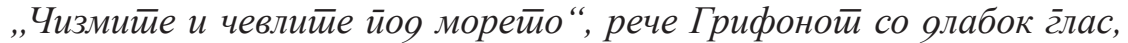
„,се рибаай со бела боја. Оіӣиму бела риба. Сегіа иии е јасно. “

(Бужаровска 2019: 117)

Each translator uses different forms of the verb рибa to translate the act of cleaning one's shoes. Temkov omits whitings from the story by simply calling them рибички, which translates as fishies, and uses a vertical pun - one component of the pun is present, the other is implicit. Buzharovska keeps whiting and includes both meanings of риба in the end to make a horizontal pun. Nevertheless, both translations result with puns which have been adapted to be understood by the target readers.

\subsection{Paronymic puns}

Paronymic puns are based on the similarity of lexical items. They are nearly identical, but have slight differences in spelling and pronunciation; they are neither quite homophones nor homographs.

"And what are they made of?" Alice asked in a tone of great curiosity.

"Soles and eels, of course," the Gryphon replied, rather impatiently: "any shrimp could have told you that." 
This exchange is a direct follow-up of the previous example; Alice is inquiring about shoes in the sea. What makes this a pun is the double meaning of soles and eels. These two words can be understood in two ways: related to sea life, and to shoes.

Soles is a homonym whose two meanings in this excerpt are:

M1 (related to sea life): a flat sea fish that is used for food

M2 (related to shoes): the bottom part of a shoe or sock

The paronymic nature of this pun is located in the word eels, whose meaning is a long thin sea or freshwater fish that looks like a snake. However, another implicit meaning can be deduced from the context. The Gryphon is talking about shoes in the sea. The pronunciation and spelling of eels is similar to heels, which is a part of a shoe.

Some of the translations omit the pun and modify the reply with items that can be found in the sea, but may also function as parts of shoes. Gjuzel and Petrovikj use школки (seashells) and јагуулска кожа/кожа оо јагула (eel skin).

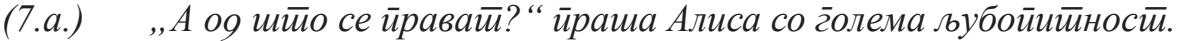

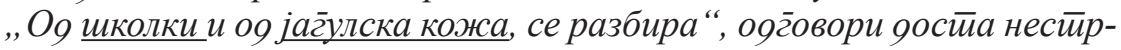

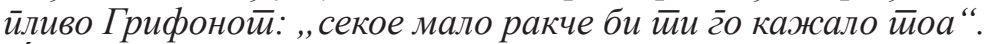
(Гуузел 1978: 75)

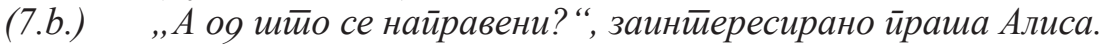
„О9 школки и оя кожа оо јагуула, се разбира“", несиирйливо ояг̄овори

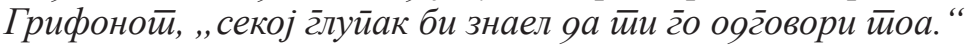
(Петровиќ 2018: 91)

The paronymic nature of the pun is reproduced by Temkov and Buzharovska. Temkov adapts the pun by using саряели (anchovies) and циииолки (mullets). Their shoe-related counterparts are саноали (sandals) and ияиеллки (tiny shoes); Buzharovska's translation includes the word црвичи (worms), which sounds similar tо врвичи (shoelaces).

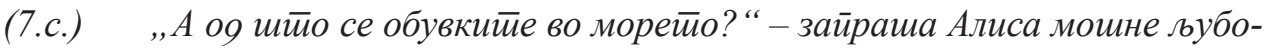
ииминоо.

„Се знае, оя саряели и цийолки “- ояг̄овори несиирйливо Јазовецой. „Секој морски йолзавец би можел тиоа яа тии го објасни. “ (Темков 1957: 93)

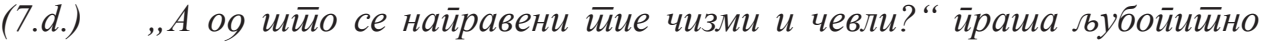
Алиса.

„Оя рибина кожа и црвии, нормално“, одг̃овори нейриееливо Грифо-

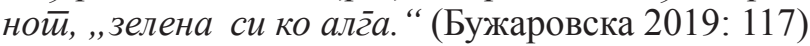

"The master was an old Turtle - we used to call him Tortoise - "

"Why did you call him Tortoise, if he wasn't one?" Alice asked.

"We called him Tortoise because he taught us," said the Mock Turtle angrily. "Really you are very dull!" 
The spelling of tortoise does not have many similarities with that of taught us, however their pronunciations are very similar - almost identical.

Gjuzel conveys the true essence of the original pun by basing his translation on the similar pronunciation of Tорйоас (Tortoise) and учеше нас (taught us), while keeping the same meaning of the original.

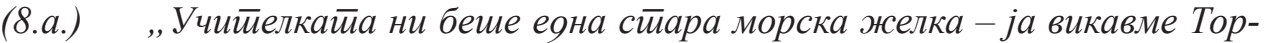
īoac..."

„А зошӣо стие ја викале Торӣоас?" йраша Алиса.

„Ја викавме Торӣоас, зашӣо нѐ учеше нас “ (Ѓузел 1978: 69)

Both Petrovikj and Buzharovska adapt Tortoise to Учииеле(е), meaning teacher. However, the rest of the exchange resumes differently in the two translations.

(8.b.) „Учител ни беше еяна многуу стиара желка, ние го викавме Учийел..."

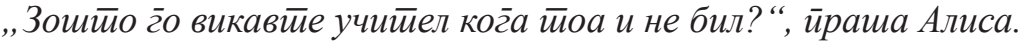

„Го викавме йака зошӣо тиој нас нѐ учеше“" (Петровиќ 2018: 83)

(8.c.) Класен ни беше еяна сіиара Желка-гоо викавме Учииеле...

„Зошито стие го викале Теле, ако бил Желка?"

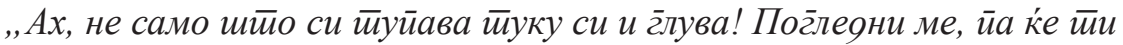
иеекне!" (Бужаровска 2019: 108)

Petrovikj keeps the 'punch line' of the pun ('because he taught us') and puns on the words Учииел and учеше - two words with the same root - учи. Although Petrovikj manages to adapt the pun, the adaptation has a shortcoming which the translator has overlooked - Petrovikj does not change Alice's reply, resulting in a situation where Alice is asking why they called their teacher Teacher (Учител), stating that he was not one, despite having translated master as учииел (teacher):

(8.d.) Back translation:

"Our teacher was a very old turtle, we called him Teacher..."

"Why did you call him 'teacher' when he wasn't one?" asked Alice.

Buzharovska's adaptation strays further from the original. This translation inserts another misunderstanding between Alice and a resident of Wonderland. After adapting Tortoise to Учииел, Buzharovska creates a misunderstanding where

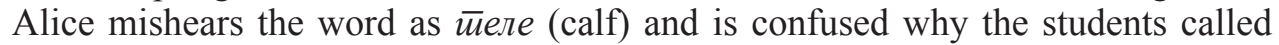
their teacher a calf, when he is a turtle.

That's the reason they're called lessons," the Gryphon remarked: "because they lessen from day to day."

The final paronymic pun has two components - lessons and lessen, similar in spelling and pronunciation, but different in meaning. 
Temkov puns with the words искусни and скусуваше. These words share a (slightly) similar pronunciation due to a segment that is pronounced the same, although the words themselves have completely differing meanings.

(9.а.) „Зайоа тиме и се викаа искусни ирреяавања“ - забележа Јазовецой„зашито секој яен се скусуваше йо еден час.“"(Темков 1957: 87)

Gjuzel and Buzharovska adapted the pun through the homograph yac. Its two meanings in the excerpts are M1: lesson ('часови' - lessons); M2: hour.

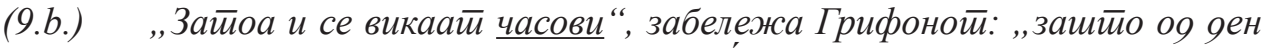
на яен се смалуваати за еяен час". (Гуузел 1978: 71)

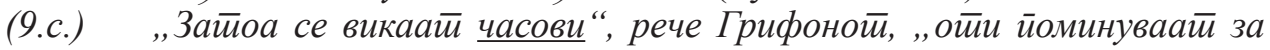
час. " (Бужаровска 2019: 111)

The others do adapt some part of the conversation, but the results are still confusing. One such example is Acevska's translation:

(9.d.) „Па зат̄иоа се нарекуваай йредавања - забележа Грифон - зайоа ийо йредаваш секој яен йо еяен час. “(Ацевска 2009: 72)

A back translation of this version would be:

(9.e.) Back translation:

"That's why they're called lessons ... because you teach for one hour every day."

Some wordplay is included through the words üpegaвaњ a (lectures) and uppegaваm (teach), but the second part of the Gryphon's explanation ('because you teach for one hour every day') makes no sense in the context of the conversation.

\section{Conclusion and discussion}

Based on the comparative analysis of a selection of nine homophonic, homographic, and paronymic puns from Alice in Wonderland, from six Macedonian translations, the following conclusions can be made:

Three translation strategies have been identified: Strategy 1: Adapting the ST with a pun/wordplay in the TT; Strategy 2: Adapting the ST without a pun/wordplay in the TT; and Strategy 3: No adaptation - the pun is lost in translation. The most frequently used strategy is Strategy 1, in $40 \%$ of the translations; second in frequency is Strategy 2, in 33\% of the translations; and the least used strategy is Strategy 3 , in $27 \%$ of the translations. 


\section{Usage of strategies throughout all translations}

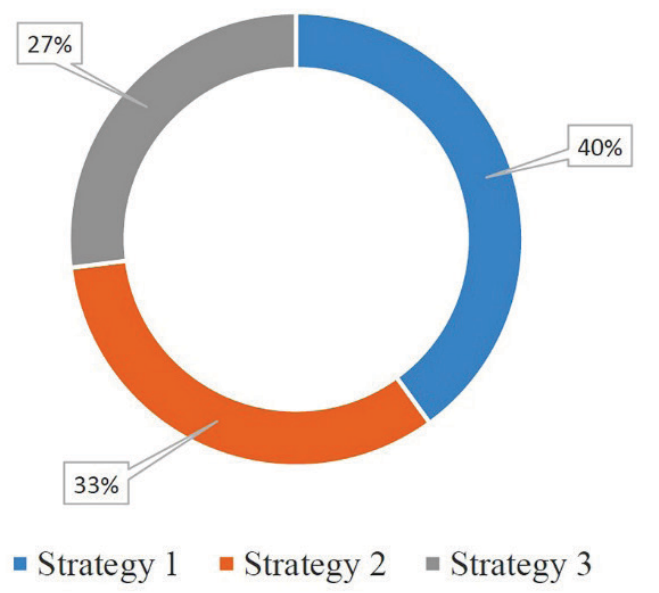

Figure 1. Usage of strategies throughout all translations

Regarding the strategies of choice of the translators, the conclusions are:

- Slavcho Temkov's (1957) uses Strategy 1 most often, in eight translations; Strategy 2 appears in three translations, and Strategy 3 in two translations.

- Bogomil Gjuzel (1978) implements Strategies 1 and 2 an equal number of times - six, and Strategy 3 in only one translation.

- Silvana Acevska 's (2009) goes with Strategy 2, used in six translations. Strategy 1 appears in four instances, and Strategy 3 is used three times.

- Negica Glasnovikj (2013) is the only translator who uses Strategy 3 most often, 11 times, while Strategies 1 and 2 appear only once.

- Marija Petrovikj (2018) goes for Strategy 2 in six instances, Strategy 3 in four, and Strategy 1 in three instances.

- Rumena Buzharovska (2019) translates the greatest number of puns using Strategy 1, using it in nine instances.Strategy 2 appears in four of her translations, and there are no recorded instances of Strategy 3. 


\section{Usage of strategies by each translator}

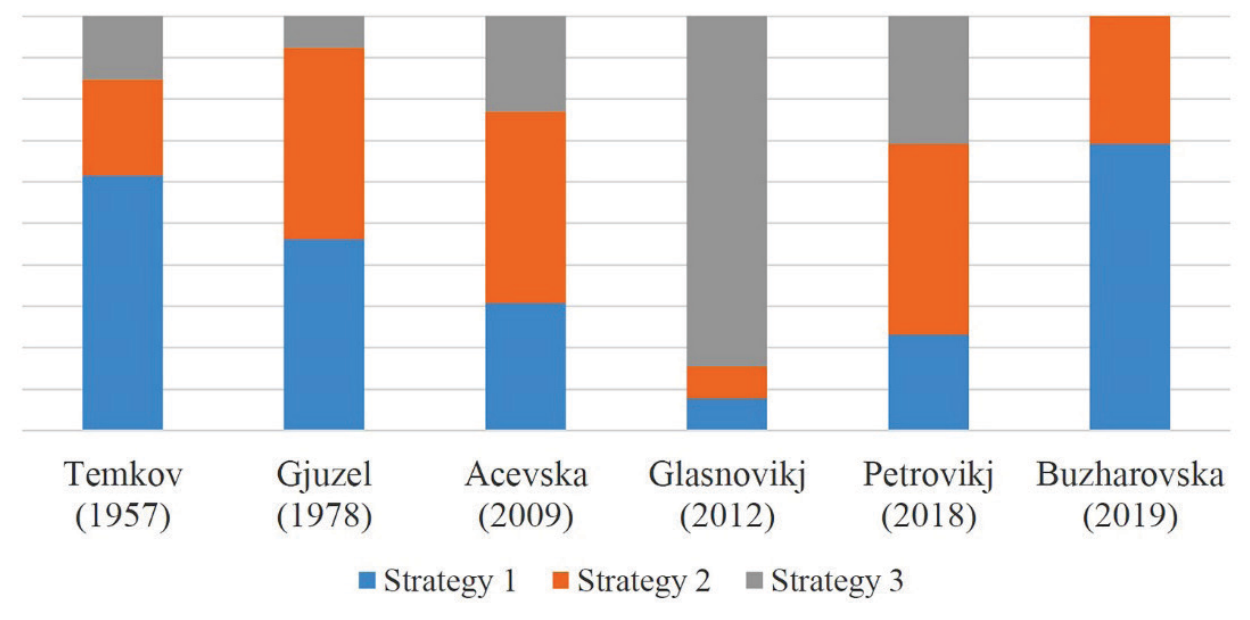

Figure 2. Usage of strategies by each translator

The results indicate that the majority of the Macedonian translators of Alice in Wonderland attempt to capture the essence of the book's wordplay by making an effort to adapt it in their own language. Most of their attempts are successful, some are adequate, and a small number - subpar, each translator interpreting the book in their own unique way. There are no noted factors influencing the choice of strategy for each translator, at least it has not been noticed by the author of this paper. The graph shows a slow decline of usage of Strategy 1, reaching an all-time low with Glasnovikj's 2012 translation and slowly picking up after that. This is not the topic of research of this paper, but it would be interesting to see a follow up research to uncover whether there were any external factors influencing the usage of strategies, or whether that remains individual to each translator. Of course, translation is very subjective, so a "winner" cannot be declared in this conclusion. There is, however, a discussion to be had about the strategies and which one is optimal. Translation often requires creativity and a certain dose of adaptation which are included in both Strategy 1 and 2. Strategy 3, however, uses a more literal or word-for-word approach that may be frowned upon by some, so it may not be deemed as the "correct" mode of translating puns, at least not in cases when better and more creative alternatives can be found.

This study confirms the fact that the complexity and intricateness of this book has captured, and will surely capture, the attention of many more translators who will be prompted to tackle the story of Alice in all its punderful glory. However, future translators must be aware of the complexity of the original, and put more effort into offering even better adaptations and creative solutions. Buzharovska's most recent translation offers a fresh and creative take on the original and is a positive step in the right direction for future translations.

Although Alice in Wonderland is an older book, it is doubtful that it will lose its popularity any time soon, so we can expect more worthy translation efforts. This 
paper can hopefully offer some insight into its existing translations to any future translators taking on the difficult task of translating this classic, as well as providing a (hopefully) interesting look into its translation history for any other curious readers.

\section{References}

Ambrosiani, P. (2010). A Russian Tail? On the Translation of Puns in Lewis Carroll's Alice's Adventures in Wonderland. Humour in Language: Linguistic and Textual Aspects. 30-63. Stockholm: USAB.

Berrani, C. G. M. (2017). Alice's Adventures in the Italian Land: Translating Children's Literature in Italy across a Century (1872-1988). PhD dissertation. University of Manchester.

Buzharovska, R. (2020). Translating Lewis Carroll's Alice In Wonderland Poems Into Macedonian. Proceedings of the ESIDRP International Conference, 21st-23rd March 2019. 245-256.

Crystal, D. (1998). Language Play. London: Penguin Books.

Delabastita, D. (1993). There's A Double Tongue: An Investigation into the Translation of Shakespeare's Wordplay, With Special Reference to Hamlet, 11. Amsterdam: Rodopi.

Delabastita, D. (1996). Introduction. Wordplay and Translation: Essays on Punning and Translation, Dirk Delabastita (ed.). 1-22. Special issue of The Translator 2 (2).

Háhn, J. (2010). Verbal humour and Lewis Carroll: a linguistic analysis of Alice's Adventures in Wonderland and Through the Looking Glass. Linguistic Shots at Humour. 7587. Kraków: Tertium.

Oxford Advanced Learner's Dictionary of Current English. (6th ed.). (2000). Oxford: Oxford University Press.

Pollack, J. (2012). The pun also rises: how the humble pun revolutionized language, changed history, and made wordplay more than some antics. New York: Penguin Random House.

Qafzezi, E. (2013). (Re)Creating the Power of Language: A Comparative Analysis on Pun

Translation in 'Alice's Adventures in Wonderland' and Its Variants in Albanian. Academic Journal of Interdisciplinary Studies, 4(2):211-221. doi: 10.5901/ajis.2012.v2n4p211

Thaler, V. (2016). Varieties of Wordplay. Crossing Languages to Play with Words. 47-62. Berlin, Germany: De Gruyter.

\section{Извори}

Карол, Луис (1957). Алиса во земјайа на чуяайа. (С. Темков, превод). Скопје: Култура. Карол, Луис (1978). Алиса во земјайа на чуяайа. (Б. Ѓузел, превод). Скопје: Култура. Карол, Луис (2013). Доживувањайа на Алиса во земјайа на чуяайа. (Н. Гласновиќ, превод). Скопје: Просветно дело.

Карол, Луис (2019). Алиса во земјайа на чуяайа. (Р. Бужаровска, превод). Скопје: Арс ламина.

Керол, Луис (2009). Алиса во земјайа на чуяайа. (С. Ацевска, превод). Скопје: Феникс.

Керол, Луис (2018). Алиса во земјайа на чуяайа. (М. Петровиќ, превод). Скопје: Матица македонска. 
